\title{
Influence of fatty acids composition in different tissue of mice feeds with fish oils
}

\author{
Influência dla composição de ácidos graxos em diferentes tecidos de camundongos alimentados com \\ óleos de peixe
}

Influencia de la composición de ácidos grasos en diferentes tejidos de ratones alimentados con aceites de pescado

Flávia Santina Pelissari Quinalha ORCID: https://orcid.org/0000-0002-5057-2205

State University of Maringá, Brazil E-mail: flaplelissari@hotmail.com

Luciana Pelissari Manin

ORCID: https://orcid.org/0000-0002-5429-5743 State University of Maringá, Brazil

E-mail: lucianapmanin@ hotmail.com

Marina Masetto Antunes

ORCID: https://orcid.org/0000-0003-4728-8518 State University of Maringá, Brazil

E-mail: marinaantunes_1992@hotmail.com

Guilherme Godoy

ORCID: https://orcid.org/0000-0003-3339-0853 State University of Maringá, Brazil

E-mail: godoy_guilherme@ @otmail.com

Marília Bellanda Galuch

ORCID: https://orcid.org/0000-0003-4728-8518 State University of Maringá, Brazil E-mail: mariliagaluch@gmail.com

Eloize Silva Alves

ORCID: https://orcid.org/0000-0002-3340-8374 State University of Maringá, Brazil

E-mail: eloizeetaus@gmail.com

Omar Cléo Neves Pereira

ORCID: https://orcid.org/0000-0001-7884-587X State University of Maringá, Brazil E-mail: omarcnpereira@gmail.com

Oscar Oliveira Santos

ORCID: https://orcid.org/0000-0002-9631-8480 State University of Maringá, Brazil

E-mail: oliveirasantos.oscardeoliveira@gmail.com

Roberto Barbosa Bazotte

ORCID: https://orcid.org/0000-0001-8563-7913 State University of Maringá, Brazil

E-mail: rbbazotte@gmail.com

Jesuí Vergílio Visentainer

ORCID: https://orcid.org/0000-0003-3412-897X State University of Maringá, Brazil E-mail: jesuivv@gmail.com

Elton Guntendorfer Bonafe

ORCID: https://orcid.org/0000-0001-7121-6368

Federal Technological University of Paraná, Brazil E-mail: eltongbonafe@gmail.com

\begin{abstract}
Omega-3 long-chain polyunsaturated fatty acids (n-3 LC-PUFA), such as eicosapentaenoic acid (EPA) and docosahexaenoic acid (DHA) play an important role in human health. Fish oils enriched with EPA and DHA have commercialized in triacylglycerol (TAG) and ethyl ester forms (EE). In this study, we compared the impact of diets containing fish oil in ethyl ester and triacylglycerol forms as a lipid source in five different tissues as liver, skeleteral muscle, brain, and epididymal white adipose tissue (WAT). The DHA levels were higher in the WAT and skeletal muscle of TAG and EE groups in comparison with the SB group. The body weight and brain, liver, epididymal WAT, and gastrocnemius muscle weights, and serum glucose, TG, cholesterol were not different between the groups. Thus,
\end{abstract}


we conclude that EPA and DHA in the form of EE or TAG influence the fatty acids composition of different tissues.

Keywords: Omega-3; EPA; DHA; Ethyl ster; TAG.

\section{Resumo}

Os ácidos graxos poliinsaturados de cadeia longa ômega-3 (n-3 AGPI-CL), como o ácido eicosapentaenóico (EPA) e o ácido docosahexaenóico (DHA), desempenham um papel importante na saúde humana. Os óleos de peixe enriquecidos com EPA e DHA foram comercializados nas formas de triacilglicerol (TAG) e éster etílico (EE). Neste estudo, comparamos o impacto de dietas contendo óleo de peixe em formas de éster etílico e triacilglicerol como fonte lipídica em cinco tecidos diferentes como fígado, músculo esquelético, cérebro e tecido adiposo branco (TAB) epididimal. Os níveis de DHA foram maiores nos grupos TAB e músculo esquelético dos grupos TAG e EE em comparação com o grupo SB. O peso corporal e os pesos do cérebro, fígado, TAB epididimal e músculos gastrocnêmios e glicose sérica, TG, colesterol não foram diferentes entre os grupos. Assim, concluímos que EPA e DHA na forma de EE ou TAG influenciam a composição de ácidos graxos de diferentes tecidos.

Palavras-chave: Ômega-3; EPA; DHA; Ester etílico; TAG.

\section{Resumen}

Los ácidos grasos poliinsaturados de cadena larga omega-3 (n-3 AGPI-CL), como el ácido eicosapentaenoico (EPA) y el ácido docosahexaenoico (DHA), desempeñan un papel importante en la salud humana. Los aceites de pescado enriquecidos con EPA y DHA se han comercializado en forma de triacilglicerol (TAG) y éster etílico (EE). En este estudio, comparamos el impacto de las dietas que contienen aceite de pescado en formas de éster etílico y triacilglicerol como fuente de lípidos en cinco tejidos diferentes como el hígado, el músculo esquelético, el cerebro y el tejido adiposo blanco epididimario (WAT). Los niveles de DHA fueron más altos en los grupos WAT y músculo esquelético de TAG y EE en comparación con el grupo SB. El peso corporal y el peso del cerebro, hígado, epidídimo WAT y músculo gastrocnemio, y glucosa sérica, TG y colesterol no fueron diferentes entre los grupos. Así, concluimos que EPA y DHA en forma de EE o TAG influyen en la composición de ácidos grasos de diferentes tejidos.

Palabras clave: Omega 3; EPA; DHA; Etil ester; TAG.

\section{Introduction}

The fatty acids (FA) are distributed in all the tissues of living organisms. They have been received special attention considering that the quantity and quality of FAs consumed in the diet play different roles in physiological processes (Wanten $\&$ Calder, 2007). Nowadays, the demand for food products enriched with omega-3 long-chain polyunsaturated fatty acids (n-3 LC-PUFA) and omega-6 long-chain polyunsaturated fatty acids (n-6 LC-PUFA) have increased. It is due their beneficial effects on human health. In especial, n-3 LC-PUFA modulates cell membrane permeability and reduces thrombosis, cardiovascular diseases, diabetes, inflammatory diseases, and neurological disorders (Wang et al., 2018).

Two important n-3 LC-PUFA are eicosapentaenoic acid (EPA) and docosahexaenoic acid (DHA). These n-3 LCPUFAs show beneficial effects in patients with hyperlipidemia, diabetes, cancers, inflammation, and neurodegenerative diseases (Dave \& Routray, 2018). EPA and DHA may be obtained from marine animals (Zhang, Xu, Wang, \& Xue, 2019) or from $\alpha$-linolenic acid (LNA) in a biossintetic process with the participation of the elongases and desaturases. Interestingly, LNA and linoleic acid (LA) are not produced in the human body. However, they be obtained from the diet (Liu et al., 2020). The synthesis of DHA from the LNA is very low, i.e., $<10 \%$ and $<3 \%$ conversion in females and males, respectively (Jeromson, Gallagher, Galloway, \& Hamilton, 2015).

Fish oil enriched with EPA and DHA can be considered a functional food because it has positive effects on health (Sarojnalini \& Hei, 2019). It is one of the most commonly prescribed supplements. The consumption of marine fish oil rich in n-3 LC-PUFA content used as a food supplement has stimulated the production in the pharmaceutical industry (Viswanathan, Verma, Ganesan, \& Manivannan, 2017). The EPA and DHA are generally commercialized as triacylglycerol ester (TAG), or ethyl ester (EE). After FAs production, the preparation of fish oil supplements by the industries occurs from two different pathways. The first step, the produced FAs reacts with enzymes to bond the FA into the glycerol molecule again (reesterification process) which results in a new TAG molecule. In the second one, the EE formed results by the reaction between 
FA and ethyl alcohol. The n-3 PUFA fish oils are found in the TAG form (MacKay, 2007).

These different chemical structures of EPA and DHA may produce differences in the bioavailability of n-3 PUFA in the bloodstream (MacKay, 2007). Ester form of FA is not usually found in the human diet. Thus, is necessary remove the ethyl group and convert the FA back into a TAG molecule during absorption (Bezard, Blond, Bernard, \& Clouet, 1994). Previous studies suggests that the uptake of free FA occurs after the hydrolysis of their esters by esterases in the intestinal lumen. Some reports have shown that EE molecular forms of FA EPA and DHA may affect absorption, bioavailability, storage, and activity in the body (Lindblom et al., 2018). However, the absorption of different forms of EPA and DHA acids is still not clear.

Some authors have reported the diet-dependence in FAs composition especially in the liver (Silva-Santi et al., (2016), skeletal muscle (Antunes et al., 2020), epididymal white adipose tissue (WAT) (Masi et al., 2017), and brain (Silva-Santi et al., 2018). Therefore, n-3 PUFA plays a specific function in various tissues.

In the liver, the DHA controls lipid metabolism stimulating $\beta$-oxidation or decreasing the FAs synthesis through the downregulation of fatty acid-synthase (Nakamura, Yudell, \& Loor, 2014). In the skeletal muscle, n-3 PUFA improve muscle anabolism in addition to reduce protein degradation (Jeromson, Gallagher, Galloway, \& Hamilton, 2015). Other study suggests that DHA regulates epididymal WAT metabolism managing pro and anti-inflammatory actions. It alleviates adipocytes abnormalities (Bargut, Santos, Machado, Aguila, \& Mandarim-de-Lacerda, 2017). In brain tissue, n-3 PUFAs improve the fluidity of neuronal membranes, acting in pivotal functions, such as the release of neurotransmitters (Meng et al., 2010). Thus, the uptake of different chemical forms of n-3 LC-PUFAs contained in fish oil supplements must be investigated. In this study, EPA and DHA in two different forms in diet were evaluated regarding the liver, brain, muscle, and epididymal WAT tissues FA composition through the incorporation of TAG and EE forms in the diet of mice.

\section{Methodology}

\subsection{Diets}

Corn starch; casein; dextrinised corn starch; microfine cellulose; mineral mix; vitamin mix; 1-cystine; choline bitartrate were obtained from Rhoster Indústria e Comércio Ltda. (Araçoiaba da Serra, São Paulo, Brazil). Sucrose was purchased from União/Camil Alimentos (Tarumã, São Paulo, Brazil). The lard was acquired from Sadia/BRF S/A (Concórdia, Santa Catarina, Brazil), soybean oil (without antioxidants) was donated by Cocamar Cooperativa Agroindustrial (Maringá, Paraná, Brazil) and omega 3 PUFA capsules were donate by NutriGenes (Maringá, Paraná, Brazil).

Diets composition were based on the purified diet for rodents proposed by the American Institute of Nutrition (AIN93-M) (Reeves, Nielsen, \& Fahey Jr, 1993) with modifications Silva-Santi et al. (2016), as described in Table 1. 
Table 1. Nutritional composition of SB, TAG and EE diets.

\begin{tabular}{lccc}
\hline Ingredients & SB $(\mathrm{g})$ & TAG $(\mathrm{g})$ & EE $(\mathrm{g})$ \\
\hline Soy oil & 0.40 & - & - \\
Fish oil TAG & - & 0.40 & 0.40 \\
Fish oil EE & - & - & 3.60 \\
Swine lard & 3.60 & 3.60 & 46.57 \\
Maize starch & 46.57 & 46.57 & 14.00 \\
Casein $(\geq 85 \%$ protein) & 14.00 & 14.00 & 15.50 \\
Dextrinized corn starch & 15.50 & 15.50 & 10.00 \\
Sucrose & 10.00 & 10.00 & 5.00 \\
Microfine cellulose & 5.00 & 5.00 & 3.50 \\
Mineral Blend $(\mathrm{AIN}-93 \mathrm{MX})^{1}$ & 3.50 & 3.50 & 1.00 \\
Vitamin blend $\left(\mathrm{AIN}-93 \mathrm{VX}^{2}\right.$ & 1.00 & 1.00 & 0.18 \\
L-Cystine & 0.18 & 0.18 & 0.25 \\
Choline bitartrate $\left(41.1 \% \mathrm{choline}^{2}\right.$ & 0.25 & 0.25 & 40 \\
Mineral water $\left(\mathrm{mL}^{2}\right.$ & 40 & 40 & 3.8 \\
Total energy $\left(\mathrm{Kcal} \mathrm{g}^{-1}\right)$ & 3.8 & 3.8 & 14.2 \\
Total protein $\left({\left.\mathrm{g} 100 \mathrm{~g}^{-1}\right)}^{\text {Total carbohydrate }\left(\mathrm{g} 100 \mathrm{~g}^{-1}\right)}\right.$ & 14.2 & 14.2 & 73.8 \\
Total fat (g $\left.100 \mathrm{~g}^{-1}\right)$ & 73.8 & 73.8 & 4.0 \\
\hline
\end{tabular}

${ }^{1}$ Mineral mixture (AIN-93M-MX): Boron = $14.26 \mathrm{mg}$; calcium = $142.94 \mathrm{~g}$; chlorine $=44.9 \mathrm{~g}$; copper = $72.41 \mathrm{mg}$; chromium = $28.65 \mathrm{mg}$; sulfur $=8.6 \mathrm{~g}$; iron $=1000 \mathrm{mg}$; fluorine $=28.72 \mathrm{mg}$; phosphorus $=56.9 \mathrm{~g}$; iodine $=5.95 \mathrm{mg}$; lithium $=2.85 \mathrm{mg}$; magnesium = $14.48 \mathrm{~g}$; manganese $=300 \mathrm{mg} ;$ molybdenum $=4.32 \mathrm{mg} ;$ nickel $=14.31 \mathrm{mg} ;$ potassium $=102.86 \mathrm{~g} ;$ selenium $=4.28 \mathrm{mg} ;$ silicon $=143.26 \mathrm{mg} ; \mathrm{sodium}$ $=29.38 \mathrm{mg}$; vanadium $=2.87 \mathrm{mg}$; zinc $=860 \mathrm{mg}$.

${ }^{2}$ Vitamin mixture $(\mathrm{AIN}-93 \mathrm{M}-\mathrm{VX}) /$ composition per kg: Folicacid $=200 \mathrm{mg}$; sonicacid $=3000 \mathrm{mg}$; biotin $=20 \mathrm{mg}$; calciumpantothenate $=$ $1600 \mathrm{mg}$; pyridoxine $\mathrm{HCl}=700 \mathrm{mg}$; riboflavin $=600 \mathrm{mg}$; thiamine $\mathrm{HCl}=600 \mathrm{mg}$; vitamin $\mathrm{A}=4000,000 \mathrm{IU}$; vitamin $\mathrm{B} 12=2500 \mu \mathrm{g}$; vitamin D3 = 100,000 IU; vitamin E = 100,000 IU; vitamin K1 = 75 mg.

SB: diet containing lard and soybean oil as a lipid source; EE: diet containing swine lard and fish oil in the form of EE as a lipid source; TAG: diet containing lard and fish oil in the form of TAG; n-6: omega 6; n-3: omega 3. Source: Authors.

\subsection{Animals and diets}

Six-week-old male Swiss mice weighing approximately $35 \mathrm{~g}$ were employed in the experiments. The animals were selected from the Central bioterium of the State University of Maringá (UEM, Maringá, Paraná, Brazil). The animals were housed under controlled temperature, humidity and photoperiod. The experimental protocol was approved by the Research Ethics Committee under number 3105210717, registered on 07/21/2017 in CEUA of UEM.

After a three-day acclimation, the mice were randomly divided into 3 groups: The control group received a diet containing lard and soybean oil as a lipid source (SB group). The EE group received swine lard and fish oil in the form of EE as a lipid source (EE group). The TAG group received lard and fish oil in the form of TAG as a lipid source (Table 1). With this procedure it was possible to determine which forms of TAG or EE, incorporated in the diet is capable of influencing the composition of FA in liver, brain, muscle, serum and epididymal WAT.

The diets were available in feeders of PVC tubes coated with metal ring to prevent material degradation. The feeder was fixed at the box, allowing only the access of the animal's head to its interior, so that the diet is not spread and allowing a more exact quantification of its consumption.

The animals were submitted to the treatment period of 56 days. Food intake was assessed daily. After the respective treatment period, the animals were weighed and fasted $15 \mathrm{~h}$ before euthanasia. The mice were euthanized and the livers, brains, muscles, and epididymal WAT were collected, quickly frozen in liquid nitrogen, and stored in a freezer at $-80{ }^{\circ} \mathrm{C}$. Serums from all animals was also collected and was used for analysis of glucose, triglycerides and cholesterol. 


\subsection{Direct Derivatization of FA}

Livers, brains, skeletal muscles and epididymal WAT were crushed still frozen, under liquid nitrogen, in a gral with the aid of pistil until obtaining homogeneous powder. The direct derivatization of FA was performed according to the method developed by Figueiredo et al. (2016). About $100 \mathrm{mg}$ of each sample was weighed into $10 \mathrm{~cm}$ high test tubes. Then $2 \mathrm{~mL}$ of $\mathrm{NaOH}\left(1.5 \mathrm{~mol} \mathrm{~L}^{-1}\right.$ in methanol) was added to the tubes and the contents were macerated with a glass stick to increase the contact surface. Then the test tubes were placed in an ultrasonic bath, Eco-Sonics Q 5.9/25 (Unique, São Paulo, Brazil) with $165 \mathrm{~W}$ of power at $25 \mathrm{kHz}$ for $5 \mathrm{~min}$ at $30^{\circ} \mathrm{C}$. Then $2 \mathrm{~mL}$ of $\mathrm{H}_{2} \mathrm{SO}_{4}\left(1.5 \mathrm{~mol} \mathrm{~L}^{-1}\right.$ in methanol) was added and the tubes were again brought to the ultrasonic bath under the above conditions. Then, $1 \mathrm{~mL}$ of $\mathrm{n}$-heptane was added to the tubes which were then stirred for $30 \mathrm{~s}$ and centrifuged at $2000 \mathrm{rpm}$ for $1 \mathrm{~min}$. Finally, $500 \mu \mathrm{L}$ of internal standard (23:0 methyl ester) was added to the tubes and the supernatant was collected and transferred to amber flasks for further chromatographic analysis. This procedure was performed for each sample in triplicate. This methodology only derives the free FAs and the TAGs present in the samples. In this way, the FAs constituting other biomolecules are not capable of being derivatized.

\subsection{FA Composition by Gas Chromatography with Flame Ionization Detector (GC-FID)}

FA methyl esters (FAMEs) were separated and quantified on a Thermo Scientific gas chromatograph, trace ultra 3300 model, equipped with a flame ionization detector, a split/splitless injector and a CP-7420 fused silica capillary column (Select FAME, $100 \mathrm{~m}$ long, $0.25 \mathrm{~mm}$ internal diameter and $0.25 \mu \mathrm{m}$ fine cyanopropyl film as the stationary phase). The operating parameters were: column temperature $165{ }^{\circ} \mathrm{C}$ for $18 \mathrm{~min}$ and then heated to $235^{\circ} \mathrm{C}\left(4^{\circ} \mathrm{C} \mathrm{min}{ }^{-1}\right)$ for 20 min; the injector and detector temperatures were kept constant at 230 and $250{ }^{\circ} \mathrm{C}$, respectively; the gas flows were $1.2 \mathrm{~mL} \mathrm{~min}^{-1}$ for the entrainment gas $\left(\mathrm{H}_{2}\right), 30 \mathrm{~mL} \mathrm{~min}^{-1}$ for the gas make up $\left(\mathrm{N}_{2}\right)$, and in the flame ionization detector, 30 and $300 \mathrm{~mL} \mathrm{~min}^{-1}$ of $\mathrm{H}_{2}$ gas and synthetic air, respectively; the samples were injected in the split mode at 1:40, in which the injection volume was $1 \mu \mathrm{L}$.

The FAMEs were identified by comparison to the retention times of the sample constituents with Sigma FAMEs. Correction factors were used to obtain the concentration values of FAs according to and the amount of FA were calculated in mg $100 \mathrm{~g}^{-1}$ of sample.

Absolute quantification of the FAMEs was performed by internal standardization using standard methyl ester of tricosanoic acid (23:0 methyl ester) (Sigma, St. Louis, USA). The percentages were determined by integrating the peak areas with the ChromQuest 5.0 software.

\subsection{Statistics Analysis}

The results were submitted to analysis of variance (ANOVA), and the means were compared by Tukey's test with a significance level of $95 \%$ using R: A language and environment for statistical computing (R Development Core Team 3.0.1., 2013).

In the fatty acid composition data, monounsaturated fatty acids, saturated fatty acids, sum of omega- 6 and 3 fatty acids, arachidonic acid, eicosapentaenoic acid, docosahexaenoic acid, SB, TAG and ethyl ester of the liver, epididymal wat and brain samples, were submitted to a multivariate exploration technique, the chosen technique was the principal component analysis (PCA), being performed in the Rstudio software version 1.4.1106.

\section{Results and Discussion}

In this study, we compared the impact of diets containing: a) lard and soybean oil as a lipid source (SB diet), b) lard and fish oil in the form of ethyl ester (EE diet) as a lipid source, c) lard and fish oil in the form of TAG (TAG diet) as a lipid source. 
It is shown the FA composition of SB diet, EE diet, and TAG diet at Table 2. The saturated FA (SFA), monounsaturated FA (MUFA), and PUFA are present in all diets. However, EPA and DHA are not present in the SB diet.

Table 2. Fatty acids composition ( $\mathrm{mg} \mathrm{g}^{-1}$ of total lipids) of SB, TAG and EE feeds.

\begin{tabular}{|c|c|c|c|}
\hline Fatty acids & SB & TAG & EE \\
\hline 14:0 & $10.24 \pm 0.39^{C}$ & $15.37 \pm 1.24^{\mathrm{A}}$ & $6.25 \pm 1.95^{\mathrm{B}}$ \\
\hline 16:0 & $154.71 \pm 5.64^{\mathrm{A}}$ & $162.95 \pm 1.74^{\mathrm{A}}$ & $88.11 \pm 26.72^{\mathrm{B}}$ \\
\hline $16: 1 n-7$ & $13.69 \pm 0.24^{\mathrm{B}}$ & $19.56 \pm 1.79^{\mathrm{A}}$ & $8.76 \pm 3.35^{\mathrm{B}}$ \\
\hline 18:0 & $74.83 \pm 4.05^{\mathrm{A}}$ & $69.68 \pm 3.59^{\mathrm{A}}$ & $42.72 \pm 10.14^{\mathrm{B}}$ \\
\hline 18:1n-9 & $227.95 \pm 6.00^{\mathrm{A}}$ & $214.42 \pm 7.72^{\mathrm{A}}$ & $110.55 \pm 40.81^{\mathrm{B}}$ \\
\hline $18: 1 n-7$ & $16.04 \pm 3.78^{\mathrm{A}}$ & $15.87 \pm 1.38^{\mathrm{A}}$ & $9.32 \pm 2.90^{\mathrm{A}}$ \\
\hline $18: 2 n-6$ & $149.12 \pm 4.87^{\mathrm{A}}$ & $111.68 \pm 5.96^{\mathrm{A}}$ & $67.37 \pm 26.61^{\mathrm{B}}$ \\
\hline $18: 3 n-3$ & $8.55 \pm 0.34^{\mathrm{A}}$ & $7.58 \pm 2.38^{\mathrm{A}}$ & $4.24 \pm 1.76^{\mathrm{A}}$ \\
\hline 20:0 & $0.41 \pm 0.08^{\mathrm{B}}$ & $0.90 \pm 0.04^{\mathrm{A}}$ & $0.57 \pm 0.10^{\mathrm{B}}$ \\
\hline $20: 1 n-9$ & $1.04 \pm 0.15^{\mathrm{A}}$ & $1.55 \pm 0.08^{\mathrm{A}}$ & $1.08 \pm 0.37^{\mathrm{A}}$ \\
\hline 22:0 & $3.48 \pm 0.22^{\mathrm{A}}$ & $3.43 \pm 0.21^{\mathrm{A}}$ & $2.07 \pm 0.77^{\mathrm{B}}$ \\
\hline $20: 3 n-3$ & $1.81 \pm 0.15^{\mathrm{A}}$ & $2.12 \pm 0.14^{\mathrm{A}}$ & $0.93 \pm 0.30^{\mathrm{B}}$ \\
\hline 20:4n-6 (AA) & $0.73 \pm 0.35^{\mathrm{A}}$ & $0.71 \pm 0.13^{\mathrm{A}}$ & $0.29 \pm 0.08^{\mathrm{A}}$ \\
\hline 20:5n-3 (EPA) & $0^{\mathrm{B}}$ & $0.57 \pm 0.08^{\mathrm{A}}$ & $0.73 \pm 0.28^{\mathrm{A}}$ \\
\hline 22:6n-3 (DHA) & $0^{\mathrm{C}}$ & $10.68 \pm 0.99^{\mathrm{A}}$ & $12.72 \pm 1.01^{\mathrm{A}}$ \\
\hline SFA & $243.66 \pm 10.20$ & $252.33 \pm 6.61$ & $139.72 \pm 39.65$ \\
\hline MUFA & $258.73 \pm 9.98$ & $251.40 \pm 10.30$ & $129.70 \pm 46.68$ \\
\hline PUFA & $160.44 \pm 4.95$ & $133.34 \pm 8.29$ & $76.28 \pm 29.43$ \\
\hline n-6 & $149.84 \pm 4.97$ & $112.39 \pm 6.07$ & $67.66 \pm 26.69$ \\
\hline n-3 & $10.60 \pm 0.25$ & $20.95 \pm 2.49$ & $8.62 \pm 2.89$ \\
\hline SFA/n-3 & $23.00 \pm 1.22$ & $12.15 \pm 1.31$ & $16.65 \pm 2.75$ \\
\hline$n-6 / n-3$ & $14.14 \pm 0.60$ & $5.40 \pm 0.41$ & $7.74 \pm 1.10$ \\
\hline SFA/PUFA & $1.52 \pm 0.02$ & $1.90 \pm 0.09$ & $1.95 \pm 0.53$ \\
\hline
\end{tabular}

SB: diet containing lard and soybean oil as a lipid source; EE: diet containing swine lard and fish oil in the form of EE as a lipid source; TAG: diet containing lard and fish oil in the form of TAG; MUFA - monounsaturated fatty acids; SFA - Saturated fatty acids; $n-6$ - sum of omega-6 fatty acids; n-3 - sum of omega-3 fatty acids; AA - arachidonic acid; EPA - eicosapentaenoic acid; DHA - docosahexaenoic acid. Source: Authors.

The main SFA were palmitic acid (16:0) and stearic acid (18:0). The main MUFA was oleic acid and the main PUFA were linoleic (18:2n-6) and $\alpha$-linolenic (18:3n-3). Linoleic (18:2n-6) and $\alpha$-linolenic (18:3n-3) are considered essential FA because they are not sinthesized in our body and must be obtained from the diet (Arterburn, Hall, \& Oken, 2006). 
Initial body weight, body weight gain, brain weight, liver weight, epididymal WAT weight, gastrocnemius muscle weight, blood glucose, triacylglycerol, and cholesterol serum levels were not different btween the groups SB, TAG and EE (Table 3).

Table 3. Initial body weight, body weight gain, gastrocnemius muscle, liver, brain, epididymal WAT weights (g) and blood levels of glucose (mg/dl), triacylglycerol (mg/dl), cholesterol (mg/dl).

\begin{tabular}{lccc}
\hline & SB & TAG & EE \\
\hline Initial body weight & $33.54 \pm 1.41^{\mathrm{A}}$ & $34.35 \pm 2.58^{\mathrm{A}}$ & $34.28 \pm 2.68^{\mathrm{A}}$ \\
Body weight gain & $19.71 \pm 4.53^{\mathrm{A}}$ & $20.01 \pm 5,94^{\mathrm{A}}$ & $16.89 \pm 5.64^{\mathrm{A}}$ \\
Brain weight & $0.43 \pm 0.04^{\mathrm{A}}$ & $0.43 \pm 0.03^{\mathrm{A}}$ & $0.42 \pm 0.04^{\mathrm{A}}$ \\
Liver weight & $1.64 \pm 0.23^{\mathrm{A}}$ & $1.83 \pm 0.44^{\mathrm{A}}$ & $1.58 \pm 0.22^{\mathrm{A}}$ \\
Epididymal WAT weight & $0.51 \pm 0.08^{\mathrm{A}}$ & $0.45 \pm 0.09^{\mathrm{A}}$ & $0.41 \pm 0.09^{\mathrm{A}}$ \\
Gastrocnemius muscle weight & $0.43 \pm 0.03^{\mathrm{A}}$ & $0.42 \pm 0.05^{\mathrm{A}}$ & $0.42 \pm 0.06^{\mathrm{A}}$ \\
Glucose & $110.29 \pm 28.21^{\mathrm{A}}$ & $102.60 \pm 21.05^{\mathrm{A}}$ & $100.07 \pm 32.84^{\mathrm{A}}$ \\
Triacylglycerol & $106.64 \pm 33.45^{\mathrm{A}}$ & $101.42 \pm 21.30^{\mathrm{A}}$ & $123.32 \pm 37.78^{\mathrm{A}}$ \\
Cholesterol & $210.00 \pm 48.76^{\mathrm{A}}$ & $212.60 \pm 67.89^{\mathrm{A}}$ & $178.90 \pm 24.67^{\mathrm{A}}$ \\
\hline
\end{tabular}

Results expressed as means \pm S.D. ( $n=9-10$ animals). Values with different letters in the same line are significantly different $(p<0.05)$ by Tukey's test; SB - control diet; TAG - triglycerides ester form; EE - free ethyl ester. Source: Authors.

Liu et al. (2020) evaluated the effect of different diets on body weight and fat mass in mice for 12 weeks and observed a slight change in the body weight gain for low n-3:n-6 ratio and SFA compared to medium and high n-3:n-6 ratios. Furthermore, the glucose, cholesterol, and triacylglycerol levels have increase with the decrease of n-3/n-6 ratios (Liu et al., 2020). Similar results have reported before with replacement from a high SFA diet to a n-3 PUFA to evaluate glucose intolerance and vascular dysfunction (Lamping et al., 2013). On the order hand just enrichment with n-3 PUFA diet did not exhibit a difference in the same parameters (Bowman et al., 2018).

The FA composition of SB diet, EE diet, and TAG in the liver it is shown in Table 4. TAG group showed higher $(p<0.05)$ content of arachidic acid (20:0), 7-hexadecanoic acid (16:1n-9), gondoic acid (20:1n-9), dihomo- $\alpha$-linolenic acid (20:3n-3), EPA (20:5n-3) and DHA (22:6n-3) in comparison with SB and EE groups. Vaccenic acid (18:1n-7) was higher in TAG when compared to the EE diet. The $\alpha$-linolenic acid $(18: 3 n-3)$ was lower $(p<0.05)$ in the TAG group concerning the EE group. EPA $(20: 5 n-3)$ was higher $(p<0.05)$ in the TAG followed by EE. In general, these results are in accordance with the previous study of Castaño-Moreno et al. (2020).

Arachidonic acid $(20: 4 n-6)$ and $\gamma$-linolenic acid $(18: 3 n-6)$ were higher $(p<0.05)$ in SB compared to TAG and EE groups. However, myristic (14:0), palmitic (16:0), and stearic acid (18:0), palmitoleic acid (16:1n-7), oleic acid (18:1n-9), nervonic acid (24:1n-9), and PUFAS linoleic acid (18:2n-6) and 11-14-eicosadienoic acid (20:2n-6) did not show difference between the groups.

Total n-3 content was higher $(p<0.05)$ in TAG treatment followed by SB and EE. Furthermore, the sequential reactions of desaturations and elongations into endogenous n-3 LC-PUFA synthesis occurs mainly in the liver (Gregory, 
Gibson, Cook-Johnson, Cleland, \& James, 2011), and high n-3 PUFA content decreased markers of hepatic lipid composition and lipogenesis (Liu et al., 2020).

Moreover, the high values of n-3 PUFA into the TAG diet imply better results to SFA:n-3, myristic acid:DHA, and n6:n-3 ratios in comparison with other treatments. The TAG diet showed the lower n-6:n-3 ratio. The balanced n-6:n-3 ratio (12/1) is associated with the prevention of cardiac diseases and obesity. Current diets in different cultures worldwide showed values ranging from 38-50 (Urban India); 16.74 (US); 15 (UK and northern Europe); 4 (Japan). Furthermore, the lower hepatic SFA: $n-3$ and n-6: $n-3$ ratios in TAG and EE groups liver could indicate a better anti-inflammatory state. In contrast, high SFA values is associated with inflammation (Simopoulos, 2016).

The tetracosanoic acid (24:0) was detected only in the SB group. The 24:0 content could be related to successive reactions of elongation and saturation. Three successive elongation reactions from oleic acid are necessary to produce that acid whose the last two steps are catalyzed by elongase 1 (Kihara, 2012).

The TAG diet exhibited higher content of arachidic acid (20:0) and gondoic acid (20:1n-9). These results are associated with the activity of elongases (Kihara, 2012). The very-long-chain composition of SFA such as arachidic acid (20:0) decreases the risk of diseases, such as diabetes. On the other hand, the composition of very-long-chain MUFAs as gondoic acid appears to decrease cardiovascular disease risk (Yang, Emma-Okon, \& Remaley, 2016).

The liver plays an important role in FA metabolism (Rui, 2014), as the synthesizes of DHA and AA from their precursors. The conversion of linoleic ( $\mathrm{n}-6$ series) and $\alpha$-linolenic ( $\mathrm{n}-3$ series) acids, respectively in DHA and AA consists of a succession of desaturation and elongation steps (Kihara, 2012). In this context, the AA is a substrate for inflammatory eicosanoids synthesis. Nevertheless, the n-3 PUFA is related to anti-inflammatory eicosanoids synthesis. Higher content of n-3 may contribute to the anti-inflammatory state in tissues of TAG (Wanten \& Calder, 2007). Also, EPA and DHA are substrates for resolvins and protectins, which are powerful anti-inflammatory molecules (Calder, 2015). 
Table 4. Fatty acids composition (mg of $\mathrm{FA} \mathrm{g}^{-1}$ sample) of liver samples.

\begin{tabular}{|c|c|c|c|}
\hline Fatty acids & SB & TAG & $\mathbf{E E}$ \\
\hline $14: 0$ & $0.50 \pm 0.04^{\mathrm{A}}$ & $0.41 \pm 0.06^{\mathrm{A}}$ & $0.49 \pm 0.07^{\mathrm{A}}$ \\
\hline $16: 0$ & $16.98 \pm 0.75^{\mathrm{A}}$ & $19.61 \pm 2.68^{\mathrm{A}}$ & $17.97 \pm 1.82^{\mathrm{A}}$ \\
\hline $18: 0$ & $3.78 \pm 0.05^{\mathrm{A}}$ & $4.25 \pm 0.67^{\mathrm{A}}$ & $4.09 \pm 0.35^{\mathrm{A}}$ \\
\hline 20:0 & $0.31 \pm 0.01^{\mathrm{A}}$ & $0.50 \pm 0.07^{\text {В }}$ & $0.30 \pm 0.04^{\mathrm{A}}$ \\
\hline $22: 0$ & $0.06 \pm 0.00^{\mathrm{A}}$ & $0.06 \pm 0.01^{\mathrm{A}}$ & $0.06 \pm 0.01^{\mathrm{A}}$ \\
\hline $24: 0$ & $0.22 \pm 0.03$ & nd & nd \\
\hline $16: 1 n-7$ & $4.55 \pm 0.28^{\mathrm{A}}$ & $3.59 \pm 0.49^{\mathrm{A}}$ & $3.95 \pm 0.42^{\mathrm{A}}$ \\
\hline $16: \ln -9$ & $0.57 \pm 0.04^{\mathrm{A}}$ & $1.21 \pm 0.15^{\text {В }}$ & $0.64 \pm 0.09^{\mathrm{A}}$ \\
\hline $18: 1 n-7$ & $3.83 \pm 0.20^{\mathrm{AB}}$ & $4.32 \pm 0.51^{\mathrm{A}}$ & $3.05 \pm 0.36^{\mathrm{B}}$ \\
\hline $18: 1 n-9$ & $29.12 \pm 1.27^{\mathrm{A}}$ & $35.72 \pm 4.93^{\mathrm{A}}$ & $27.40 \pm 3.31^{\mathrm{A}}$ \\
\hline $20: \ln -9$ & $0.10 \pm 0.00^{\mathrm{A}}$ & $0.15 \pm 0.02^{\text {В }}$ & $0.10 \pm 0.02^{\mathrm{A}}$ \\
\hline $24: 1 n-9$ & $0.03 \pm 0.02^{\mathrm{A}}$ & $0.10 \pm 0.05^{\mathrm{A}}$ & $0.03 \pm 0.01^{\mathrm{A}}$ \\
\hline $18: 2 n-6$ & $7.75 \pm 0.40^{\mathrm{A}}$ & $7.06 \pm 0.97^{\mathrm{A}}$ & $7.48 \pm 0.68^{\mathrm{A}}$ \\
\hline $18: 3 n-6$ & $0.30 \pm 0.04^{\mathrm{A}}$ & $0.15 \pm 0.04^{\mathrm{B}}$ & $0.18 \pm 0.01^{\mathrm{B}}$ \\
\hline $20: 2 n-6$ & $0.18 \pm 0.01^{\mathrm{A}}$ & $0.18 \pm 0.02^{\mathrm{A}}$ & $0.14 \pm 0.02^{\mathrm{A}}$ \\
\hline $20: 4 n-6$ (AA) & $4.43 \pm 0.04^{\mathrm{A}}$ & $3.06 \pm 0.38^{\text {В }}$ & $3.12 \pm 0.23^{\mathrm{B}}$ \\
\hline $18: 3 n-3$ & $0.11 \pm 0.02^{\mathrm{AB}}$ & $0.09 \pm 0.01^{\mathrm{A}}$ & $0.14 \pm 0.01^{\mathrm{B}}$ \\
\hline $20: 3 n-3$ & $0.36 \pm 0.02^{\mathrm{A}}$ & $0.62 \pm 0.07^{\text {В }}$ & $0.45 \pm 0.04^{\mathrm{A}}$ \\
\hline $20: 5 n-3$ (EPA) & $0.03 \pm 0.02^{\mathrm{A}}$ & $0.37 \pm 0.04^{\mathrm{B}}$ & $0.21 \pm 0.01^{\mathrm{C}}$ \\
\hline 22:6n-3 (DHA) & $1.39 \pm 0.10^{\mathrm{A}}$ & $2.69 \pm 0.39^{\text {в }}$ & $0.14 \pm 0.00^{\mathrm{C}}$ \\
\hline \multicolumn{4}{|c|}{ SUMS AND RATIOS } \\
\hline SFA & $21.85 \pm 0.88^{\mathrm{A}}$ & $24.83 \pm 3.49^{\mathrm{A}}$ & $22.91 \pm 2.29^{\mathrm{A}}$ \\
\hline MUFA & $38.20 \pm 1.81^{\mathrm{A}}$ & $45.09 \pm 6.15^{\text {В }}$ & $35.17 \pm 4.21^{\mathrm{AB}}$ \\
\hline PUFA & $14.55 \pm 0.65^{\mathrm{A}}$ & $14.22 \pm 1.92^{\mathrm{A}}$ & $11.86 \pm 1^{\mathrm{A}}$ \\
\hline $\mathrm{n}-6$ & $12.66 \pm 0.49^{\mathrm{A}}$ & $10.45 \pm 1.41^{\mathrm{A}}$ & $10.92 \pm 0.94^{\mathrm{A}}$ \\
\hline$n-3$ & $1.89 \pm 0.16^{\mathrm{A}}$ & $3.77 \pm 0.51^{\mathrm{B}}$ & $0.94 \pm 0.06^{\mathrm{B}}$ \\
\hline $\mathrm{SFA} / \mathrm{n}-3$ & $11.56 \pm 5.5^{\mathrm{A}}$ & $6.59 \pm 6.84^{\mathrm{B}}$ & $24.37 \pm 38.17^{\mathrm{C}}$ \\
\hline$n-6 / n-3$ & $6.70 \pm 3.06^{\mathrm{A}}$ & $2.77 \pm 2.76^{\mathrm{B}}$ & $11.61 \pm 15.67^{\mathrm{B}}$ \\
\hline
\end{tabular}

Results expressed as means \pm S.D. of three replicates. Values with different letters in the same line are significantly different $(p<0.05)$ by Tukey's test; SB - control diet; TAG - triglycerides ester form; EE - free ethyl ester; SFA - saturated fatty acids; MUFA - monounsaturated fatty acids; PUFA - polyunsaturated fatty acids; n-3 - omega 3 fatty acids; n-6 - omega 6 fatty acids; SUM: sum of all fatty acids evaluated; nd - not detected. Source: Authors.

In skeletal muscle (Table 5), the content of 24:0, 24:1n-9, 20:4n-6, and 20:3n-3 were higher $(p<0.05)$ in the SB diet when compared with TAG and EE groups. In muscle, the higher amount of tetracosanoic is related to higher inflammation 
(Antunes et al., 2020). There was no statistical difference among the myristic, palmitic, stearic, docosanoic, arachidic, palmitoleic, 7-hexadecanoic, vaccenic, oleic, gondoic, linoleic, $\gamma$-linoleic, 11-14-eicosanoic, $\alpha$-linolenic, and EPA content between all the diets.

Table 5. Fatty acids composition (mg of $\mathrm{FA} \mathrm{g}^{-1}$ sample) of skeletal muscle samples.

\begin{tabular}{|c|c|c|c|}
\hline Fatty acids & SB & TAG & EE \\
\hline $14: 0$ & $0.62 \pm 0.07^{\mathrm{A}}$ & $0.60 \pm 0.16^{\mathrm{A}}$ & $0.61 \pm 0.06^{\mathrm{A}}$ \\
\hline $16: 0$ & $8.79 \pm 0.95^{\mathrm{A}}$ & $9.74 \pm 3.42^{\mathrm{A}}$ & $8.93 \pm 0.54^{\mathrm{A}}$ \\
\hline $18: 0$ & $1.33 \pm 0.04^{\mathrm{A}}$ & $1.61 \pm 0.68^{\mathrm{A}}$ & $1.37 \pm 0.13^{\mathrm{A}}$ \\
\hline $20: 0$ & $0.16 \pm 0.02^{\mathrm{A}}$ & $0.16 \pm 0.06^{\mathrm{A}}$ & $0.16 \pm 0.01^{\mathrm{A}}$ \\
\hline $22: 0$ & $0.05 \pm 0.01^{\mathrm{A}}$ & $0.04 \pm 0.01^{\mathrm{A}}$ & $0.05 \pm 0.00^{\mathrm{A}}$ \\
\hline $24: 0$ & $0.08 \pm 0.01^{\mathrm{A}}$ & $0.02 \pm 0.01^{\mathrm{B}}$ & $0.02 \pm 0.00^{\mathrm{B}}$ \\
\hline $16: 1 n-7$ & $5.22 \pm 0.51^{\mathrm{A}}$ & $4.49 \pm 1.10^{\mathrm{A}}$ & $4.47 \pm 0.37^{\mathrm{A}}$ \\
\hline $16: 1 n-9$ & $0.30 \pm 0.02^{\mathrm{A}}$ & $0.32 \pm 0.07^{\mathrm{A}}$ & $0.25 \pm 0.03^{\mathrm{A}}$ \\
\hline $18: 1 n-7$ & $2.00 \pm 0.25^{\mathrm{A}}$ & $1.78 \pm 0.49^{\mathrm{A}}$ & $1.64 \pm 0.18^{\mathrm{A}}$ \\
\hline $18: 1 n-9$ & $15.07 \pm 2.14^{\mathrm{A}}$ & $15.59 \pm 5.50^{\mathrm{A}}$ & $13.93 \pm 1.19^{\mathrm{A}}$ \\
\hline $20: 1 n-9$ & $0.04 \pm 0.01^{\mathrm{A}}$ & $0.04 \pm 0.01^{\mathrm{A}}$ & $0.04 \pm 0.00^{\mathrm{A}}$ \\
\hline $24: 1 n-9$ & $0.14 \pm 0.02^{\mathrm{A}}$ & $0.03 \pm 0.00^{\mathrm{B}}$ & $0.04 \pm 0.00^{\mathrm{B}}$ \\
\hline $18: 2 n-6$ & $4.69 \pm 0.53^{\mathrm{A}}$ & $5.38 \pm 2.75^{\mathrm{A}}$ & $4.14 \pm 0.20^{\mathrm{A}}$ \\
\hline $18: 3 n-6$ & $0.08 \pm 0.06^{\mathrm{A}}$ & $0.05 \pm 0.03^{\mathrm{A}}$ & $0.13 \pm 0.00^{\mathrm{A}}$ \\
\hline $20: 2 n-6$ & $0.06 \pm 0.00^{\mathrm{A}}$ & $0.03 \pm 0.00^{\mathrm{A}}$ & $0.03 \pm 0.00^{\mathrm{A}}$ \\
\hline $20: 4 n-6(A A)$ & $0.85 \pm 0.06^{\mathrm{A}}$ & $0.43 \pm 0.03^{\mathrm{B}}$ & $0.47 \pm 0.03^{\mathrm{B}}$ \\
\hline $18: 3 n-3$ & $0.11 \pm 0.06^{\mathrm{A}}$ & $0.20 \pm 0.14^{\mathrm{A}}$ & $0.03 \pm 0.00^{\mathrm{A}}$ \\
\hline $20: 3 n-3$ & $0.11 \pm 0.00^{\mathrm{A}}$ & $0.08 \pm 0.01^{\mathrm{B}}$ & $0.08 \pm 0.01^{\mathrm{B}}$ \\
\hline $20: 5 n-3$ (EPA) & $0.01 \pm 0.00^{\mathrm{A}}$ & $0.01 \pm 0.00^{\mathrm{A}}$ & $0.03 \pm 0.02^{\mathrm{A}}$ \\
\hline 22:6n-3 (DHA) & $0.42 \pm 0.03^{\mathrm{A}}$ & $0.88 \pm 0.15^{\mathrm{B}}$ & $0.89 \pm 0.07^{\mathrm{B}}$ \\
\hline \multicolumn{4}{|c|}{ SUMS AND RATIOS } \\
\hline SFA & $11.03 \pm 1.1^{\mathrm{A}}$ & $12.17 \pm 4.34^{\mathrm{B}}$ & $11.14 \pm 0.74^{\mathrm{A}}$ \\
\hline MUFA & $22.77 \pm 2.95^{\mathrm{A}}$ & $22.25 \pm 7.17^{\mathrm{A}}$ & $20.37 \pm 1.77^{\mathrm{B}}$ \\
\hline PUFA & $6.33 \pm 0.74^{\mathrm{A}}$ & $7.06 \pm 3.11^{\mathrm{A}}$ & $5.8 \pm 0.33^{\mathrm{A}}$ \\
\hline$n-6$ & $5.68 \pm 0.65^{\mathrm{A}}$ & $5.89 \pm 2.81^{\mathrm{A}}$ & $4.77 \pm 0.23^{\mathrm{B}}$ \\
\hline$n-3$ & $0.65 \pm 0.09^{\mathrm{A}}$ & $1.17 \pm 0.3^{\mathrm{B}}$ & $1.03 \pm 0.1^{\mathrm{B}}$ \\
\hline $\mathrm{SFA} / \mathrm{n}-3$ & $16.97 \pm 12.22^{\mathrm{A}}$ & $10.40 \pm 14.47^{\mathrm{B}}$ & $10.81 \pm 7.4^{\mathrm{B}}$ \\
\hline$n-6 / n-3$ & $8.74 \pm 7.22^{\mathrm{A}}$ & $5.03 \pm 9.37^{\mathrm{B}}$ & $4.63 \pm 2.3^{\mathrm{B}}$ \\
\hline
\end{tabular}

Results expressed as means \pm S.D. of three replicates. Values with different letters in the same line are significantly different $(p<0.05)$ by Tukey's test; SB - control diet; TAG - triglycerides ester form; EE - free ethyl ester; SFA - saturated fatty acids; MUFA - monounsaturated fatty acids; PUFA - polyunsaturated fatty acids; n-3 - omega 3 fatty acids; n- 6 - omega 6 fatty acids; SUM: sum of all fatty acids evaluated. Source: Authors. 
On the other hand, the incorporation of DHA was over $100 \%(p<0.05)$ higher in the TAG and EE groups in comparison with the control group. Jeromson, Gallagher, Galloway, \& Hamilton (2015) reported that at least 2 weeks of a new diet are enough to promote significant change in its lipid composition and showed that skeletal muscle is responsive to the diet changes. Brown et al. (2019) have exhibited that n-3 LC-PUFA (EPA and DHA) displayed beneficial effects on skeletal muscle protein turnover. And the anti-inflammatory response played by n-3 PUFA can be a key role in the preservation of lean muscle mass in post-operative cancer patients (Ryan et al., 2009).

The total SFA was higher $(p<0.05)$ in the TAG group than in SB and EE treatments. Total MUFA and n-6 were lower $(p<0.05)$ in the EE group, compared to the others. The sum of $n-3$ was lower $(p<0.05)$ in the SB group compared to TAG and EE. The SFA/n-3 and n-6/n-3 ratios were higher $(p<0.05)$ in the SB in comparison with TAG and EE groups. In this way, the n-3 enriched diet contributed to decreasing the n-6/n-3 ratio wich can have beneficial effects in the body. The western diet has a high n-6/n-3 ratio of 20:1; High content of n- 6 PUFA cause an unbalanced ratio since the lack of n-3 PUFA. The unbalance among n-3 and n-6 PUFA may exacerbate a pro-inflammatory state (Jeromson, Gallagher, Galloway, \& Hamilton, 2015).

Rocha-Rodrigues et al. (2017) evaluated the impact of physical exercise on FA of the WAT in response to a high-fat diet regimen. They found the same FA quantified in this study (Table 6). The SB diet showed higher $(p<0.05)$ content of eicosadienoic acid than TAG and EE treatments.

Table 6. Fatty acids composition (mg of FA g ${ }^{-1}$ sample) of epididymal WAT samples.

\begin{tabular}{|c|c|c|c|}
\hline Fatty acids & SB & TAG & EE \\
\hline $14: 0$ & $5.93 \pm 0.56^{\mathrm{A}}$ & $6.14 \pm 0.30^{\mathrm{A}}$ & $6.80 \pm 0.37^{\mathrm{A}}$ \\
\hline $16: 0$ & $120.15 \pm 13.0^{\mathrm{A}}$ & $130.25 \pm 4.89^{\mathrm{A}}$ & $136.85 \pm 6.91^{\mathrm{A}}$ \\
\hline 18:0 & $12.39 \pm 1.20^{\mathrm{A}}$ & $13.21 \pm 1.13^{\mathrm{A}}$ & $14.87 \pm 0.63^{\mathrm{A}}$ \\
\hline $20: 0$ & $3.44 \pm 0.22^{\mathrm{A}}$ & $3.36 \pm 0.18^{\mathrm{A}}$ & $3.86 \pm 0.28^{\mathrm{A}}$ \\
\hline $22: 0$ & $0.89 \pm 0.07^{\mathrm{A}}$ & $0.75 \pm 0.12^{\mathrm{A}}$ & $0.77 \pm 0.02^{\mathrm{A}}$ \\
\hline $16: 1 \mathrm{n}-7$ & $44.14 \pm 2.90^{\mathrm{A}}$ & $40.47 \pm 1.45^{\mathrm{A}}$ & $41.72 \pm 2.32^{\mathrm{A}}$ \\
\hline $16: 1 n-9$ & $6.08 \pm 0.5^{\mathrm{A}}$ & $6.47 \pm 0.88^{\mathrm{A}}$ & $7.08 \pm 0.45^{\mathrm{A}}$ \\
\hline $18: 1 n-7$ & $24.15 \pm 3.37^{\mathrm{A}}$ & $24.36 \pm 0.36^{\mathrm{A}}$ & $27.77 \pm 2.17^{\mathrm{A}}$ \\
\hline $18: 1 n-9$ & $277.98 \pm 29.09^{\mathrm{A}}$ & $271.47 \pm 7.25^{\mathrm{A}}$ & $294.28 \pm 14.99^{\mathrm{A}}$ \\
\hline $20: 1 n-9$ & $0.69 \pm 0.04^{\mathrm{A}}$ & $0.61 \pm 0.09^{\mathrm{A}}$ & $0.74 \pm 0.03^{\mathrm{A}}$ \\
\hline $24: 1 n-9$ & $0.03 \pm 0.00^{\mathrm{A}}$ & $0.06 \pm 0.02^{\mathrm{A}}$ & $0.06 \pm 0.02^{\mathrm{A}}$ \\
\hline $18: 2 n-6$ & $91.63 \pm 7.25^{\mathrm{A}}$ & $86.05 \pm 4.14^{\mathrm{A}}$ & $93.25 \pm 5.23^{\mathrm{A}}$ \\
\hline $18: 3 n-6$ & $0.74 \pm 0.05^{\mathrm{A}}$ & $0.63 \pm 0.10^{\mathrm{A}}$ & $0.60 \pm 0.19^{\mathrm{A}}$ \\
\hline $20: 2 n-6$ & $0.66 \pm 0.10^{\mathrm{A}}$ & $0.37 \pm 0.04^{\mathrm{B}}$ & $0.32 \pm 0.01^{\mathrm{B}}$ \\
\hline $20: 4 n-6(A A)$ & $0.12 \pm 0.01^{\mathrm{A}}$ & $0.11 \pm 0.02^{\mathrm{A}}$ & $0.11 \pm 0.02^{\mathrm{A}}$ \\
\hline $18: 3 n-3$ & $3.72 \pm 0.36^{\mathrm{A}}$ & $3.43 \pm 0.30^{\mathrm{A}}$ & $3.24 \pm 0.16^{\mathrm{A}}$ \\
\hline $20: 3 n-3$ & $0.54 \pm 0.04^{\mathrm{A}}$ & $0.36 \pm 0.06^{\mathrm{B}}$ & $0.35 \pm 0.02^{\mathrm{B}}$ \\
\hline $20: 5 n-3$ (EPA) & $0.14 \pm 0.01^{\mathrm{A}}$ & $0.20 \pm 0.03^{\mathrm{B}}$ & $0.25 \pm 0.03^{\mathrm{B}}$ \\
\hline $22: 6 n-3$ (DHA) & $0.06 \pm 0.00^{\mathrm{A}}$ & $0.20 \pm 0.03^{\mathrm{B}}$ & $0.16 \pm 0.01^{\mathrm{B}}$ \\
\hline
\end{tabular}




\begin{tabular}{cccc}
\hline & SUMS AND RATIOS & & \\
\hline SFA & $142.8 \pm 15.05^{\mathrm{A}}$ & $153.71 \pm 6.62^{\mathrm{A}}$ & $163.15 \pm 8.21^{\mathrm{A}}$ \\
MUFA & $356.07 \pm 35.90^{\mathrm{A}}$ & $343.44 \pm 10.05^{\mathrm{A}}$ & $371.65 \pm 19.98^{\mathrm{A}}$ \\
PUFA & $97.61 \pm 7.82^{\mathrm{A}}$ & $91.35 \pm 4.72^{\mathrm{A}}$ & $98.28 \pm 5.67^{\mathrm{A}}$ \\
$\mathrm{n}-6$ & $93.15 \pm 7.41^{\mathrm{A}}$ & $87.16 \pm 4.3^{\mathrm{A}}$ & $94.28 \pm 5.45^{\mathrm{A}}$ \\
n-3 & $4.46 \pm 0.41^{\mathrm{A}}$ & $4.19 \pm 0.42^{\mathrm{A}}$ & $4 \pm 0.22^{\mathrm{A}}$ \\
SFA/n-3 & $32.02 \pm 36.71^{\mathrm{A}}$ & $36.68 \pm 15.76^{\mathrm{B}}$ & $40.79 \pm 37.32^{\mathrm{A}}$ \\
$\mathrm{n}-6 / \mathrm{n}-3$ & $20.88 \pm 18.07^{\mathrm{A}}$ & $20.80 \pm 10.24^{\mathrm{B}}$ & $23.57 \pm 24.77^{\mathrm{A}}$ \\
\hline
\end{tabular}

Results expressed as means \pm S.D. of three replicates. Values with different letters in the same line are significantly different $(P<0.05)$ by Tukey's test; SB - control diet; TAG - triglycerides ester form; EE - free ethyl ester; SFA - saturated fatty acids; MUFA - monounsaturated fatty acids; PUFA - polyunsaturated fatty acids; n-3 - omega 3 fatty acids; n- 6 - omega 6 fatty acids; SUM: sum of all fatty acids evaluated. Source: Authors.

However, in the WAT the EPA and DHA had higher amounts $(p<0.05)$ in TAG and EE groups in comparison with the SB diet. Earlier study reported that the ability to storage DHA is limited in concerning with brain, liver, and muscle. This can be related with the substantial escape of DHA, liberated by lipoprotein lipase from WAT to the blood (Arterburn, Hall, \& Oken, 2006).

The SB group showed higher content of dihomo- $\alpha$-linolenic acid (20:3n-3), resulting from the elongation of $\alpha$ linolenic acid (18:3n-3) (Ichi et al., 2014). The deposition of myristic acid (14:0), palmitic acid (16:0), stearic acid (18:0), arachidic acid (20:0), palmitoleic acid (16:1n-7), 7-hexadecanoic acid (16:1n-9), vaccenic acid (18:1n-7), oleic acid (18:1n-9), gondoic acid (20:1n-9), nervonic acid (24:1-9), linoleic acid (18:2n-6), $\gamma$-linolenic acid (18:3n-6), arachidonic acid (20:4n-6), and $\alpha$-linolenic acid (18:3n-3) was similar among all the diets.

(Bargut, Santos, Machado, Aguila, \& Mandarim-de-Lacerda (2017) studied the effect of EPA and DHA intake on epididymal WAT submitted a high fructose diet. They reported that the epididymal fat mass content was equivalent in all the groups. Zhang, Xu, Wang, \& Xue (2019) have also reported similar results about epididymal WAT. The palmitic, oleic, and linoleic are the most common FA esterified into WAT triglycerides. They compose about 85\% of the total FA in WAT triglycerides (Rocha-Rodrigues et al., 2017). This corroborates with the results found here where the 16:0, 18:1n-9, and 18:2n6 acids content corresponds to $83 \%$ of all the FA quantified in this tissue.

The TAG and EE groups showed lower 11-14-eicosadienoic acid in epididymal WAT. Also, the diets showed no difference in the total SFA, MUFA, PUFA, n-6, and n-3. However, SFA:n-3 and n-6:n-3 ratios were higher (p<0.05) in the EE than in SB and TAG groups.

In the brain the content of myristic (14:0), palmitic (16:0), stearic (18:0), arachidic (20:0), docosanoic (22:0), palmitoleic (16:1n-7), 7-hexadecanoic (16:1n-9), vaccenic (18:1n-7), oleic (18:1n-9), gondoic (20:1n-9), linoleic (18:2n-6), $\gamma$ linolenic (18:3n-6), 11,14-eicosadienoic (20:2n-6), arachidonic (20:4n-6), $\alpha$-linolenic (18:3n-3), dihomo- $\alpha$-linolenic (20:3n-3), EPA (20:5n-3) and DHA (22:6n-3) acids were not different for SB group, TAG group and EE group (Table 7). These results are in agreement with previous studies (Jung et al., 2017). Luchtman, Meng \& Song (2012) investigated the influence of ethylesters supplementation on Parkinson's disease. But they did not observe changes in the DHA content. 
Table 7. Fatty acids composition (mg of FA g ${ }^{-1}$ sample) of brain samples.

\begin{tabular}{|c|c|c|c|}
\hline Fatty acids & SB & TAG & $\mathbf{E E}$ \\
\hline $14: 0$ & & $0.05 \pm 0.01^{\mathrm{A}}$ & $0.04 \pm 0.03^{\mathrm{A}}$ \\
\hline $16: 0$ & $6.69 \pm 1.09^{\mathrm{A}}$ & $5.66 \pm 0.42^{\mathrm{A}}$ & $5.78 \pm 0.89^{\mathrm{A}}$ \\
\hline 18:0 & $6.21 \pm 0.87^{\mathrm{A}}$ & $5.32 \pm 0.44^{\mathrm{A}}$ & $5.35 \pm 0.78^{\mathrm{A}}$ \\
\hline $20: 0$ & $0.68 \pm 0.01^{\mathrm{A}}$ & $0.61 \pm 0.06^{\mathrm{A}}$ & $0.66 \pm 0.13^{\mathrm{A}}$ \\
\hline $22: 0$ & $0.03 \pm 0.00^{\mathrm{A}}$ & $0.02 \pm 0.00^{\mathrm{A}}$ & $0.03 \pm 0.00^{\mathrm{A}}$ \\
\hline $24: 0$ & $0.72 \pm 0.08^{\mathrm{A}}$ & $0.57 \pm 0.06^{\mathrm{A}}$ & $0.58 \pm 0.08^{\mathrm{A}}$ \\
\hline $16: 1 n-7$ & $0.23 \pm 0.03^{\mathrm{A}}$ & $0.22 \pm 0.03^{\mathrm{A}}$ & $0.25 \pm 0.03^{\mathrm{A}}$ \\
\hline $16: 1 n-9$ & $0.04 \pm 0.01^{\mathrm{A}}$ & $0.03 \pm 0.01^{\mathrm{A}}$ & $0.04 \pm 0.01^{\mathrm{A}}$ \\
\hline $18: 1 n-7$ & $1.36 \pm 0.16^{\mathrm{A}}$ & $1.12 \pm 0.06^{\mathrm{A}}$ & $1.17 \pm 0.16^{\mathrm{A}}$ \\
\hline $18: 1 n-9$ & $5.45 \pm 0.70^{\mathrm{A}}$ & $4.96 \pm 0.41^{\mathrm{A}}$ & $5.20 \pm 0.85^{\mathrm{A}}$ \\
\hline $20: \ln -9$ & $0.18 \pm 0.01^{\mathrm{A}}$ & $0.14 \pm 0.03^{\mathrm{A}}$ & $0.17 \pm 0.04^{\mathrm{A}}$ \\
\hline $24: 1 n-9$ & $0.14 \pm 0.04^{\mathrm{A}}$ & $0.05 \pm 0.00^{\mathrm{B}}$ & $0.05 \pm 0.01^{\mathrm{B}}$ \\
\hline $18: 2 n-6$ & $0.12 \pm 0.01^{\mathrm{A}}$ & $0.13 \pm 0.01^{\mathrm{A}}$ & $0.14 \pm 0.01^{\mathrm{A}}$ \\
\hline $18: 3 n-6$ & $0.01 \pm 0.00^{\mathrm{A}}$ & $0.01 \pm 0.00^{\mathrm{A}}$ & $0.02 \pm 0.00^{\mathrm{A}}$ \\
\hline $20: 2 n-6$ & $0.04 \pm 0.00^{\mathrm{A}}$ & $0.05 \pm 0.01^{\mathrm{A}}$ & $0.05 \pm 0.01^{\mathrm{A}}$ \\
\hline 20:4n-6 (AA) & $2.40 \pm 0.37^{\mathrm{A}}$ & $1.87 \pm 0.11^{\mathrm{A}}$ & $1.84 \pm 0.28^{\mathrm{A}}$ \\
\hline $18: 3 n-3$ & $0.12 \pm 0.01^{\mathrm{A}}$ & $0.11 \pm 0.01^{\mathrm{A}}$ & $0.12 \pm 0.0^{\mathrm{A}}$ \\
\hline $20: 3 n-3$ & $0.12 \pm 0.01^{\mathrm{A}}$ & $0.15 \pm 0.01^{\mathrm{A}}$ & $0.13 \pm 0.02^{\mathrm{A}}$ \\
\hline 20:5n-3 (EPA) & $0.05 \pm 0.02^{\mathrm{A}}$ & $0.06 \pm 0.01^{\mathrm{A}}$ & $0.06 \pm 0.01^{\mathrm{A}}$ \\
\hline $22: 6 n-3$ (DHA) & $3.36 \pm 0.51^{\mathrm{A}}$ & $3.08 \pm 0.19^{\mathrm{A}}$ & $3.04 \pm 0.43^{\mathrm{A}}$ \\
\hline \multicolumn{4}{|c|}{ SUMS AND RATIOS } \\
\hline SFA & $14.38 \pm 2.05^{\mathrm{A}}$ & $12.23 \pm 0.99^{\mathrm{A}}$ & $12.44 \pm 1.91^{\mathrm{A}}$ \\
\hline MUFA & $7.4 \pm 0.95^{\mathrm{A}}$ & $6.51 \pm 0.54^{\mathrm{A}}$ & $6.88 \pm 1.1^{\mathrm{A}}$ \\
\hline PUFA & $6.22 \pm 0.93^{\mathrm{A}}$ & $5.46 \pm 0.35^{\mathrm{A}}$ & $5.40 \pm 0.76^{\mathrm{A}}$ \\
\hline$n-6$ & $2.57 \pm 0.38^{\mathrm{A}}$ & $2.06 \pm 0.13^{\mathrm{A}}$ & $2.05 \pm 0.3^{\mathrm{A}}$ \\
\hline$n-3$ & $3.65 \pm 0.55^{\mathrm{A}}$ & $3.4 \pm 0.22^{\mathrm{A}}$ & $3.35 \pm 0.46^{\mathrm{A}}$ \\
\hline $\mathrm{SFA} / \mathrm{n}-3$ & $3.94 \pm 3.73^{\mathrm{A}}$ & $3.59 \pm 4.5^{\mathrm{A}}$ & $3.71 \pm 4.15^{\mathrm{A}}$ \\
\hline$n-6 / n-3$ & $0.70 \pm 0.69^{\mathrm{A}}$ & $0.60 \pm 0.59^{\mathrm{A}}$ & $0.61 \pm 0.65^{\mathrm{A}}$ \\
\hline
\end{tabular}

Results expressed as means \pm S.D. of three replicates. Values with different letters in the same line are significantly different $(P<0.05)$ by Tukey's test; SB - control diet; TAG - triglycerides ester form; EE - free ethyl ester; SFA - saturated fatty acids; MUFA monounsaturated fatty acids; PUFA - polyunsaturated fatty acids; n-3 - omega 3 fatty acids; n- 6 - omega 6 fatty acids; SUM: sum of all fatty acids evaluated. Source: Authors.

The treatments also did not differ in total SFA, MUFA, PUFA, n-6, n-3, and in SFA/n-3, n-6/n-3 ratios, and the sum of all the FA evaluated was similar in the groups. The diets only differ in the deposition of nervonic acid (24:1n-9) and the 
tetracosanoic acid (24:0) that were higher $(p<0.05)$ in the SB group. The tetracosanoic acid (24:0) and nervonic acid $(24: 1 \mathrm{n}-9)$ are found in high amounts of sphingolipids. They are components of membranes and modulators of cell-cell interactions and cell recognition. In the brain, high amounts of tetracosanoic acid (24:0) have reported as harmful for cells (Schönfeld \& Reiser, 2016). Differing, nervonic acid (24:1n-9) in the brain displays an important role like an intermediate in myelin biosynthesis (Jana \& Pahan, 2010).

The brain has a FA composition tightly regulated and exhibits lower response to diet composition changes in comparison with liver, skeletal muscle, and heart (Silva-Santi et al., 2018). In addition, the brain displays a preference for DHA uptake concerning the other FAs. Not always brain DHA levels are dependent on dietary n-3 PUFA. The dietary n-3 PUFA deficiency has more impact in some specific situations as pregnancy and lactation (Levant, Ozias, \& Carlson, 2006).

In general, the changes observed in FAs of the liver, muscle and epididymal WAT tissues the sum of all the FA evaluated, SFA, MUFA, and PUFA were similar between the groups. SFA is associated with the development of metabolic dysfunction. On the other hand, some MUFAs, and PUFAs have been linked to the positive effects on metabolic function (Jeromson, Gallagher, Galloway, \& Hamilton, 2015). Higher n-3 PUFA content of TAG and EE diets were not able to limit TG deposition in the liver, as reported by Di Minno et al. (2012) moreover, the TAG and EE groups presented decreased in some n-6 PUFA as AA either in liver and muscle and 11-14-eicosadienoic acid in epididymal WAT. These results are in agreement with other studies that showed decreased AA contents with DHA supplementation (Arterburn, Hall, \& Oken, 2006).

To the best view of the data, the principal component analysis (PCA) has been applied. The variables evaluated were AA, DHA, EPA, n-3 PUFA, n-6 PUFA, MUFA, and SFA in three treatments (SB, TAG, and EE). We choose two components to explain all data (Figure $1 \mathrm{~A}$ ). The first component (PC1) explained $86.86 \%$ of the variance. The second component (PC2) explained $12.93 \%$. Thus, the sum of PC1 and PC2 results at $99.79 \%$ of the total data variance. Part B of Figure 1 shows the proximity of all the samples forming two distinct groups. The liver, muscle, and epididymal specimens generated the first group. The second group was composed by brain samples. The MUFA and SFA variables are responsible for the formation of two groups due to the higher negative eigenvalues. The higher positive eigenvalues were the EPA, DHA, AA, and n-3 variables. The biggest difference found among the results obtained for the brain is because the FA composition of the brain is less sensitive to diet changes (Silva-Santi et al., 2018). 
Figure 1. Scree plot (A), scores (B), and loadings on PCA of all the samples.
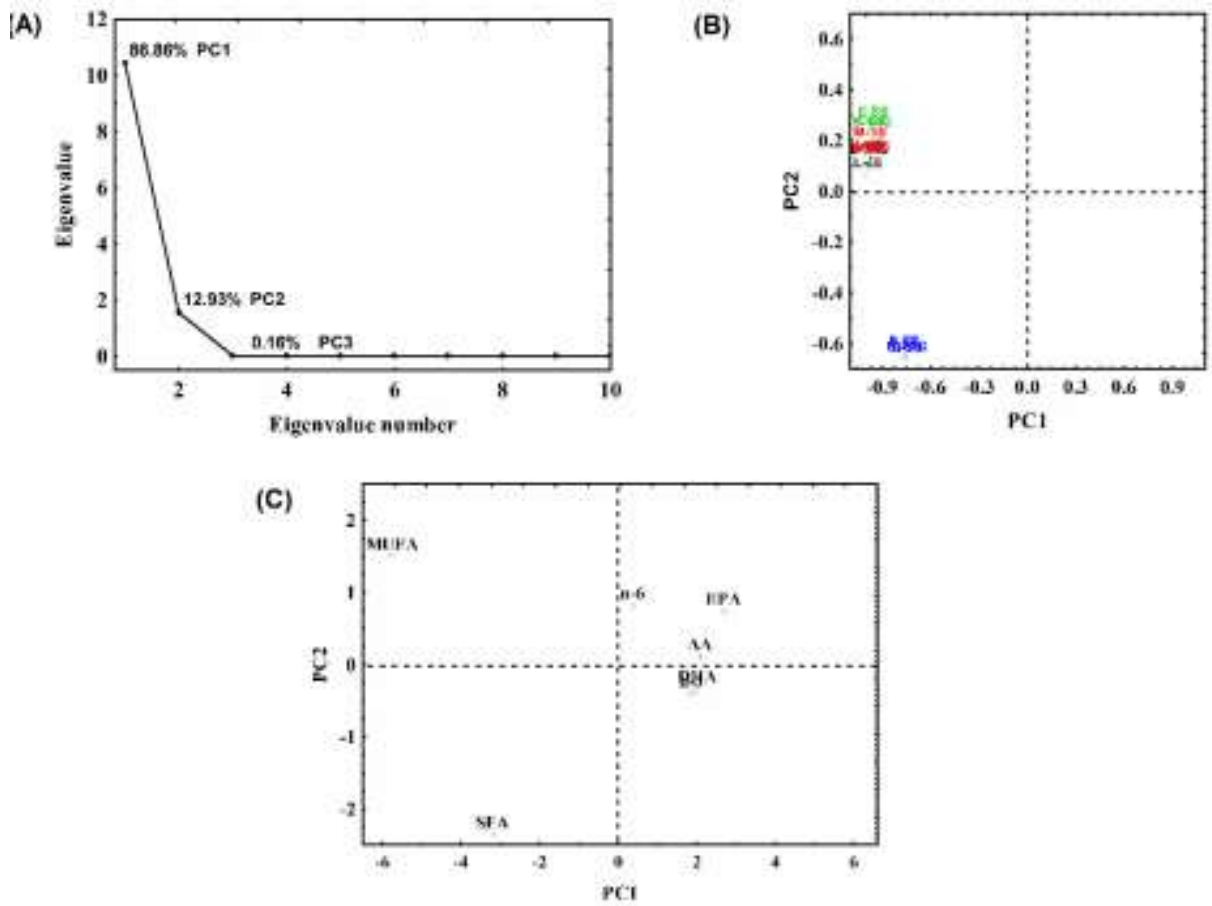

MUFA - monounsaturated fatty acids; SFA - Saturated fatty acids; n- 6 - sum of omega- 6 fatty acids; n-3 - sum of omega-3 fatty acids; AA - arachidonic acid; EPA - eicosapentaenoic acid; DHA - docosahexaenoic acid; L-(SB, TAG, and EE) - liver samples; M-(SB, TAG, and EE) - muscle samples; E-(SB, TAG, and EE) - epididymal wat samples; B-(SB, TAG, and EE) - brain samples. Source: Authors.

\section{Conclusion}

For the first time, we showed the influence in the fatty acid composition of liver, brain, skeletal muscle, and epididymal WAT in mouse's model fed with different chemical structures of n-3 long-chain fatty acids like EPA and DHA. The increase of DHA content in the skeletal muscle and epididymal WAT compared to the control diet proves the LC-PUFA n-3 accumulation. Furthermore, the performance animal parameters did not display a difference among all the samples. Therefore, EPA and DHA in the form of EE or TAG influence the FA composition in muscle, liver, and epididymal WAT, but not in the brain. The authors suggest that further studies should be carried out with other animal species, including fish included in the diet of the present study, since it influenced the fatty acid composition of the tissues of mice and could positively affect health.

\section{Acknowledgments}

The authors are grateful to Conselho Nacional de Desenvolvimento Científico e Tecnológico (CNPQ, Grant numbers 420675/2018-3), Coordenação de Aperfeiçoamento de Pessoal de Nível Superior (CAPES), and Fundação Araucária de Apoio ao Desenvolvimento Científico e Tecnológico do Estado do Paraná (FAPPR) for financial assistance. 


\section{References}

Antunes, M. M., Godoy, G., de Almeida-Souza, C. B., da Rocha, B. A., da Silva-Santi, L. G., Masi, L. N., ... \& Bazotte, R. B. (2020). A high-carbohydrate diet induces greater inflammation than a high-fat diet in mouse skeletal muscle. Brazilian Journal of Medical and Biological Research, 53(3).

Arterburn, L. M., Hall, E. B., \& Oken, H. (2006). Distribution, interconversion, and dose response of n- 3 fatty acids in humans. The American journal of clinical nutrition, 83(6), 1467S-1476S

Bargut, T. C. L., Santos, L. P., Machado, D. G. L., Aguila, M. B., \& Mandarim-de-Lacerda, C. A. (2017). Eicosapentaenoic acid (EPA) vs. Docosahexaenoic acid (DHA): Effects in epididymal white adipose tissue of mice fed a high-fructose diet. Prostaglandins, Leukotrienes and Essential Fatty Acids, $123,14-24$.

Bezard, J., Blond, J. P., Bernard, A., \& Clouet, P. (1994). The metabolism and availability of essential fatty acids in animal and human tissues. Reproduction Nutrition Development, 34(6), 539-568.

Bowman, L., Mafham, M., Wallendszus, K., Stevens, W., Buck, G., Barton, J., ... Armitage, J. (2018). Effects of n-3 fatty acid supplements in diabetes mellitus. New England Journal of Medicine, 379(16), 1540-1550.

Brown, K. M., Sharma, S., Baker, E., Hawkins, W., van der Merwe, M., \& Puppa, M. J. (2019). Delta-6-desaturase (FADS2) inhibition and omega-3 fatty acids in skeletal muscle protein turnover. Biochemistry and biophysics reports, 18, 100622.

Calder, P. C. (2015). Functional roles of fatty acids and their effects on human health. Journal of parenteral and enteral nutrition, 39, 18S-32S.

Castaño-Moreno, E., Castillo, V., Peñailillo, R., Llanos, M. N., Valenzuela, R., \& Ronco, A. M. (2020). Fatty acid and lipid metabolism in liver of pregnant mice and their offspring is influenced by unbalanced folates/vitamin B12 diets. Prostaglandins, Leukotrienes and Essential Fatty Acids, $154,102057$.

Dave, D., \& Routray, W. (2018). Current scenario of Canadian fishery and corresponding underutilized species and fishery byproducts: A potential source of omega-3 fatty acids. Journal of Cleaner Production, 180, 617-641.

Di Minno, M. N. D., Russolillo, A., Lupoli, R., Ambrosino, P., Di Minno, A., \& Tarantino, G. (2012). Omega-3 fatty acids for the treatment of non-alcoholic fatty liver disease. World journal of gastroenterology: WJG, 18(41), 5839.

Figueiredo, I. L., Claus, T., Júnior, O. O. S., Almeida, V. C., Magon, T., \& Visentainer, J. V. (2016). Fast derivatization of fatty acids in different meat samples for gas chromatography analysis. Journal of Chromatography A, 1456, 235-241.

Gregory, M. K., Gibson, R. A., Cook-Johnson, R. J., Cleland, L. G., \& James, M. J. (2011). Elongase reactions as control points in long-chain polyunsaturated fatty acid synthesis. PloS one, 6(12), e29662.

Ichi, I., Kono, N., Arita, Y., Haga, S., Arisawa, K., Yamano, M., ... \& Arai, H. (2014). Identification of genes and pathways involved in the synthesis of Mead acid (20: 3n-9), an indicator of essential fatty acid deficiency. Biochimica et Biophysica Acta (BBA)-Molecular and Cell Biology of Lipids, 1841(1), $204-213$.

Jana, A., \& Pahan, K. (2010). Sphingolipids in multiple sclerosis. Neuromolecular medicine, 12(4), 351-361.

Jeromson, S., Gallagher, I. J., Galloway, S. D., \& Hamilton, D. L. (2015). Omega-3 fatty acids and skeletal muscle health. Marine drugs, 13(11), 6977-7004.

Jung, J. M., Lee, J., Kim, K. H., Jang, I. G., Song, J. G., Kang, K., ... \& Kim, H. W. (2017). The effect of lead exposure on fatty acid composition in mouse brain analyzed using pseudo-catalytic derivatization. Environmental Pollution, 222, 182-190.

Kihara, A. (2012). Very long-chain fatty acids: elongation, physiology and related disorders. The journal of biochemistry, 152(5), 387-395

Lamping, K. G., Nuno, D. W., Coppey, L. J., Holmes, A. J., Hu, S., Oltman, C. L., ... \& Yorek, M. A. (2013). Modification of high saturated fat diet with n-3 polyunsaturated fat improves glucose intolerance and vascular dysfunction. Diabetes, Obesity and Metabolism, 15(2), 144-152.

Levant, B., Ozias, M. K., \& Carlson, S. E. (2006). Diet (n-3) polyunsaturated fatty acid content and parity interact to alter maternal rat brain phospholipid fatty acid composition. The Journal of nutrition, 136(8), 2236-2242.

Lindblom, A., Ericsson, C., Hagstedt, T., Kjellstedt, A., Oscarsson, J., \& Oakes, N. D. (2018). Uptake and tissue accretion of orally administered free carboxylic acid as compared to ethyl ester form of docosahexaenoic acid (DHA) in the rat. Plos one, $13(8), \mathrm{e} 0201367$.

Liu, R., Chen, L., Wang, Y., Zhang, G., Cheng, Y., Feng, Z., ... \& Liu, J. (2020). High ratio of $\omega-3 / \omega-6$ polyunsaturated fatty acids targets mTORC1 to prevent high-fat diet-induced metabolic syndrome and mitochondrial dysfunction in mice. The Journal of nutritional biochemistry, $79,108330$.

Luchtman, D. W., Meng, Q., \& Song, C. (2012). Ethyl-eicosapentaenoate (E-EPA) attenuates motor impairments and inflammation in the MPTP-probenecid mouse model of Parkinson's disease. Behavioural brain research, 226(2), 386-396.

MacKay, D. (2007). A Comparison of Synthetic Ethyl Ester Form Fish Oil vs. Natural Triglyceride Form. http://www.promedics.ca/site/downloads/Triglycerides\%20vs\%20Ethyl\%20Esters.pdf

Masi, L. N., Martins, A. R., Crisma, A. R., do Amaral, C. L., Davanso, M. R., Serdan, T. D. A., ... \& Curi, R. (2017). Combination of a high-fat diet with sweetened condensed milk exacerbates inflammation and insulin resistance induced by each separately in mice. Scientific reports, 7(1), 1-10.

Meng, Q., Luchtman, D. W., El Bahh, B., Zidichouski, J. A., Yang, J., \& Song, C. (2010). Ethyl-eicosapentaenoate modulates changes in neurochemistry and brain lipids induced by parkinsonian neurotoxin 1-methyl-4-phenylpyridinium in mouse brain slices. European journal of pharmacology, 649(1-3), 127-134.

Nakamura, M. T., Yudell, B. E., \& Loor, J. J. (2014). Regulation of energy metabolism by long-chain fatty acids. Progress in lipid research, 53 , $124-144$.

R Development Core Team 3.0.1. (2013). A Language and Environment for Statistical Computing. R Foundation for Statistical Computing, 2, https://www.R- 
Research, Society and Development, v. 10, n. 16, e338101623706, 2021

(CC BY 4.0) | ISSN 2525-3409 | DOI: http://dx.doi.org/10.33448/rsd-v10i16.23706

project.org.

Reeves, P. G., Nielsen, F. H., \& Fahey Jr, G. C. (1993). AIN-93 purified diets for laboratory rodents: final report of the American Institute of Nutrition ad hoc writing committee on the reformulation of the AIN-76A rodent diet.

Rocha-Rodrigues, S., Rodríguez, A., Gonçalves, I. O., Moreira, A., Maciel, E., Santos, S., ... \& Magalhães, J. (2017). Impact of physical exercise on visceral adipose tissue fatty acid profile and inflammation in response to a high-fat diet regimen. The international journal of biochemistry \& cell biology, 87, 114-124.

Rui, L. (2014). Energy metabolism in the liver. Comprehensive physiology, 4(1), 177.

Ryan, A. M., Reynolds, J. V., Healy, L., Byrne, M., Moore, J., Brannelly, N., .. \& Flood, P. (2009). Enteral nutrition enriched with eicosapentaenoic acid (EPA) preserves lean body mass following esophageal cancer surgery: results of a double-blinded randomized controlled trial. Annals of surgery, 249(3), 355363.

Sarojnalini, C., \& Hei, A. (2019). Fish as an important functional food for quality life. U: Functional foods,(Lagouri, V., ured.), IntechOpen, London, $77-97$.

Schönfeld, P., \& Reiser, G. (2016). Brain lipotoxicity of phytanic acid and very long-chain fatty acids. Harmful cellular/mitochondrial activities in Refsum disease and X-linked adrenoleukodystrophy. Aging and disease, 7(2), 136.

Silva-Santi, D., Gimenez, L., Antunes, M. M., Caparroz-Assef, S. M., Carbonera, F., Masi, L. N., ... \& Bazotte, R. B. (2016). Liver fatty acid composition and inflammation in mice fed with high-carbohydrate diet or high-fat diet. Nutrients, 8(11), 682.

Silva-Santi, L. G., Masetto Antunes, M., Mori, M. A., Biesdorf de Almeida-Souza, C., Vergílio Visentainer, J., Carbonera, F., ... \& Barbosa Bazotte, R. (2018). Brain fatty acid composition and inflammation in mice fed with high-carbohydrate diet or high-fat diet. Nutrients, 10(9), 1277.

Simopoulos, A. P. (2016). An increase in the omega-6/omega-3 fatty acid ratio increases the risk for obesity. Nutrients, 8(3), 128.

Viswanathan, S., Verma, P. R. P., Ganesan, M., \& Manivannan, J. (2017). A novel liquid chromatography/tandem mass spectrometry (LC-MS/MS) based bioanalytical method for quantification of ethyl esters of Eicosapentaenoic acid (EPA) and Docosahexaenoic acid (DHA) and its application in pharmacokinetic study. Journal of pharmaceutical and biomedical analysis, 141, 250-261.

Wang, L., Fan, H., He, J., Wang, L., Tian, Z., \& Wang, C. (2018). Protective effects of omega-3 fatty acids against Alzheimer's disease in rat brain endothelial cells. Brain and behavior, 8(11), e01037.

Wanten, G. J., \& Calder, P. C. (2007). Immune modulation by parenteral lipid emulsions. The American journal of clinical nutrition, 85(5), 1171-1184.

Yang, Z. H., Emma-Okon, B., \& Remaley, A. T. (2016). Dietary marine-derived long-chain monounsaturated fatty acids and cardiovascular disease risk: a mini review. Lipids in health and disease, 15(1), 1-9.

Zhang, T. T., Xu, J., Wang, Y. M., \& Xue, C. H. (2019). Health benefits of dietary marine DHA/EPA-enriched glycerophospholipids. Progress in lipid research, 75, 100997. 